\title{
Chemical composition and acetylcholinesterase inhibition of the essential oil of Cyathocalyx pruniferus (Maingay ex Hook.f. \& Thomson) J. Sinclair
}

Wan Mohd Nuzul Hakimi Wan Salleh ${ }^{1,}$, (D) Shamsul Khamis ${ }^{2}$, (D) Muhammad Helmi Nadri, (iD) Hakimi Kassim ${ }^{4}$ and (D) Alene Tawang ${ }^{4}$

${ }^{1}$ Department of Chemistry, Faculty of Science and Mathematics, Universiti Pendidikan Sultan Idris, 35900 Tanjong Malim, Perak, MALAYSIA

${ }^{2}$ School of Environmental and Natural Sciences, Faculty of Science and Technology, Universiti Kebangsaan Malaysia, 43600 Bangi, Selangor, MALAYSIA

${ }^{3}$ Innovation Centre in Agritechnology (ICA), Universiti Teknologi Malaysia, Hub Pendidikan Tinggi Pagoh, 84600 Pagoh, Muar, Johor, MALAYSIA

${ }^{4}$ Department of Biology, Faculty of Science and Mathematics, Universiti Pendidikan Sultan Idris, 35900 Tanjong Malim, Perak, MALAYSIA

*Corresponding author. Email: wmnhakimi@fsmt.upsi.edu.my

Submitted: 16.07.2020; Accepted: 24.11.2020

\section{Abstract}

The chemical composition and acetylcholinesterase inhibitory activity of the essential oil from the leaf of Cyathocalyx pruniferus growing in Pahang, Malaysia was investigated for the first time. The essential oil was obtained by hydrodistillation and fully characterized by gas chromatography (GC) and gas chromatography-mass spectrometry (GC-MS). A total of thirty chemical components (95.5\%) were successfully identified in the essential oil which was characterized by high proportions of $\alpha$-pinene (25.4\%), germacrene D (20.2\%), $\beta$-caryophyllene (10.8\%), and $\delta$-cadinene (6.4\%). Acetylcholinesterase inhibitory activity was evaluated against the Ellman method, and the essential oil showed good inhibition against acetylcholinesterase (Percentage inhibition: $75.5 \%)$ assay.

Keywords: Essential oil, Cyathocalyx pruniferus, Annonaceae, $\alpha$-pinene, germacrene D, acetylcholinesterase

\section{Introduction}

The genus Cyathocalyx belonging to the Annonaceae family consists of approximately 36 species of monopodial trees. It is widely distributed in primary and secondary tropical lowland forests of Southeast Asia, with a center of diversity in western Malaysia (Peninsular Malaysia, Sumatra, and Borneo) (Wang and Saunders, 2006). Cyathocalyx pruniferus (Maingay ex Hook.f. \& Thomson) J. Sinclair. is locally known as Antoi beludu in Malaysia (Burkill, 1966). International Plant Names Index reported that the plant is a synonym of Drepananthus pruniferus Maingay ex Hook.f. \& Thomson (IPNI, 2020). Literature reviews indicated that only a small number of species in the genus Cyathocalyx have been investigated for its chemical compounds and biological activities. Previous phytochemical investigation on Cyathocalyx species led to the isolation of alkaloids and diterpenoids (Wijeratne et al., 1995a, 1995b). However, there is little information about the chemical composition and the biological properties of the essential oil of the genus Cyathocalyx. Previous study on the essential oil of Cyathocalyx have been reported on Cyathocalyx zeylanicus collected from India (Hisham et al., 2012). In continuation of our systematic studies on pharmacologically active volatiles from Malaysian plants (Salleh et al.,2014, 2015a, 2015b, 2016a, 2016b), we describe in this paper an evaluation of the chemical composition and acetylcholinesterase inhibitory activity of the essential oil from the leaf of $C$. pruniferus. 


\section{Materials and Methods}

\section{Plant material}

Sample of Cyathocalyx pruniferus was collected from Gambang, Pahang in September 2019, and identified by Dr. Shamsul Khamis from Universiti Kebangsaan Malaysia (UKM). The voucher specimen (SK242/19) was deposited at UKMB Herbarium, Faculty of Science and Technology UKM.

\section{Extraction of essential oil}

The fresh leaf ( $300 \mathrm{~g}$ ) was subjected to hydrodistillation in Clevenger-type apparatus for 4 hours. The essential oil obtained was dried over anhydrous magnesium sulphate and stored at $4-6^{\circ} \mathrm{C}$.

\section{Gas chromatography (GC) analysis}

GC analysis were performed on an Agilent Technologies 7890B and an Agilent 7890B FID equipped with DB5 column. Helium was used as a carrier gas at a flow rate of $0.7 \mathrm{~mL} / \mathrm{min}$. Injector and detector temperature were set at 250 and $280^{\circ} \mathrm{C}$, respectively. The oven temperature was kept at $50{ }^{\circ} \mathrm{C}$, then gradually raised to $280^{\circ} \mathrm{C}$ at $5^{\circ} \mathrm{C} / \mathrm{min}$ and finally held isothermally for $15 \mathrm{~min}$. Diluted samples ( $1 / 100$ in diethyl ether, $\left.\mathrm{v} / \mathrm{v}\right)$ of $1.0 \mu \mathrm{L}$ were injected manually (split ratio 50:1). The injection was repeated three times and the peak area percentages were reported as means \pm SD of triplicates. Calculation of peak area percentage was carried out by using the GC HP Chemstation software (Agilent Technologies).

\section{Gas chromatography-mass spectrometry (GC-MS) analysis}

GC-MS chromatograms were recorded using Agilent Technologies 7890A and Agilent 5975 GC MSD equipped. The GC was equipped with HP-5MS column. Helium was used as carrier gas at a flow rate of $1 \mathrm{~mL} / \mathrm{min}$. Injector temperature was $250{ }^{\circ} \mathrm{C}$. The oven temperature was programmed from $50{ }^{\circ} \mathrm{C}$ ( 5 min hold) to $250{ }^{\circ} \mathrm{C}$ at 10 ${ }^{\circ} \mathrm{C} / \mathrm{min}$ and finally held isothermally for $15 \mathrm{~min}$. For GC-MS detection, an electron ionization system, with ionization energy of $70 \mathrm{eV}$ was used. A scan rate of $0.5 \mathrm{~s}$ (cycle time: $0.2 \mathrm{~s}$ ) was applied, covering a mass range from $40-400$ amu.

\section{Identification of chemical components}

For identification of essential oil components, co-injection with the standards (major components) were used, together with correspondence of retention indices and mass spectra with respect to those occurring in Adams, NIST 08 and FFNSC2 libraries (Adams, 2007). Semi-quantification of essential oil components was made by peak area normalization considering the same response factor for all volatile components. Percentages values were the mean of three chromatographic analyses.

\section{Acetylcholinesterase inhibitory activity}

AChE inhibitory activity of the essential oil was measured by slightly modifying the spectrophotometric method developed by Salleh et al. (2014b). Electric eel AChE was used, while acetylthiocholine iodide was employed as substrates of the reaction. DTNB acid was used for the measurement of the acetylcholinesterase activity. Briefly, in this method, $140 \mu \mathrm{L}$ of sodium phosphate buffer ( $\mathrm{pH} 8.0$ ), $20 \mu \mathrm{L}$ of DTNB, $20 \mu \mathrm{L}$ of essential oil and $20 \mu \mathrm{L}$ of AChE solution were added by multichannel automatic pipette in a 96-well microplate and incubated for $15 \mathrm{~min}$ at $25^{\circ} \mathrm{C}$. The reaction was then initiated with the addition of $10 \mu \mathrm{L}$ of acetylthiocholine iodide. Hydrolysis of acetylthiocholine iodide was monitored by the formation of the yellow 5-thio-2nitrobenzoate anion as a result of the reaction of DTNB with thiocholines, catalysed by enzymes at $412 \mathrm{~nm}$ utilizing a 96-well microplate reader (Epoch Micro-Volume Spectrophotometer, USA). Percentage of 
inhibition (\%l) of AChE was determined by comparison of rates of reaction of samples relative to blank sample (EtOH in phosphate buffer $\mathrm{pH} 8$ ) using the formula: \% $=[\mathrm{E}-\mathrm{S} / \mathrm{E}] \times 100$; where $\mathrm{E}$ is the activity of enzyme without test sample and $\mathrm{S}$ is the activity of enzyme with test sample. The experiments were done in triplicate. Galantamine was used as a reference.

\section{Statistical analysis}

Data obtained from essential oil analysis and bioactivity were expressed as mean values. The statistical analyses were carried out by employing one-way ANOVA $(p<0.05)$. A statistical package (SPSS version 11.0) was used for the data analysis.

\section{Results and Discussion}

The essential oil was isolated by hydrodistillation from the fresh leaf of $C$. pruniferus was analysed by gas chromatography (GC) and gas chromatography-mass spectrometry (GC-MS). The yield of the essential oil obtained was $0.13 \%(w / w)$. The percentage composition of the essential oil, retention time and retention indices of the components are shown in Table 1.

Table 1. Chemical composition of $C$. pruniferus essential oil

\begin{tabular}{|c|c|c|c|c|}
\hline No. & Components & $\mathrm{KI}^{\mathrm{a}}$ & $\mathrm{KI}^{\mathrm{b}}$ & Percentage (\%) \\
\hline 1 & $\alpha$-Pinene & 930 & 0932 & $25.4 \pm 0.3$ \\
\hline 2 & Camphene & 945 & 946 & $0.4 \pm 0.1$ \\
\hline 3 & Sabinene & 970 & 0969 & $0.4 \pm 0.1$ \\
\hline 4 & $\beta$-Pinene & 972 & 0974 & $1.1 \pm 0.1$ \\
\hline 5 & $\alpha$-Terpinene & 1015 & 1014 & $0.4 \pm 0.2$ \\
\hline 6 & Limonene & 1025 & 1024 & $0.3 \pm 0.1$ \\
\hline 7 & $\beta$-Elemene & 1336 & 1335 & $0.5 \pm 0.1$ \\
\hline 8 & $\alpha$-Cubebene & 1346 & 1345 & $0.9 \pm 0.1$ \\
\hline 9 & $\alpha$-Copaene & 1376 & 1374 & $1.1 \pm 0.1$ \\
\hline 10 & $\beta$-Caryophyllene & 1415 & 1417 & $10.8 \pm 0.3$ \\
\hline 11 & Aromadendrene & 1440 & 1439 & $1.3 \pm 0.1$ \\
\hline 12 & $\alpha$-Humulene & 1450 & 1452 & $0.3 \pm 0.2$ \\
\hline 13 & Alloaromadendrene & 1460 & 1458 & $0.5 \pm 0.2$ \\
\hline 14 & $\alpha$-Amorphene & 1485 & 1483 & $1.1 \pm 0.1$ \\
\hline 15 & Germacrene D & 1486 & 1484 & $20.2 \pm 0.2$ \\
\hline 16 & $\beta$-Selinene & 1490 & 1489 & $0.3 \pm 0.2$ \\
\hline 17 & $\alpha$-Muurolene & 1505 & 1500 & $0.5 \pm 0.2$ \\
\hline 18 & $\beta$-Bisabolene & 1502 & 1505 & $0.8 \pm 0.1$ \\
\hline 19 & $(E, E)$ - $\alpha$-Farenesene & 1505 & 1505 & $2.6 \pm 0.2$ \\
\hline 20 & $\gamma$-Cadinene & 1510 & 1513 & $0.5 \pm 0.1$ \\
\hline 21 & $\delta$-Cadinene & 1520 & 1522 & $6.4 \pm 0.1$ \\
\hline 22 & Elemol & 1550 & 1548 & $0.7 \pm 0.1$ \\
\hline 23 & Germacrene B & 1560 & 1559 & $2.4 \pm 0.3$ \\
\hline 24 & $(E)$-Nerolidol & 1560 & 1561 & $1.2 \pm 0.1$ \\
\hline
\end{tabular}




\begin{tabular}{|c|c|c|c|c|}
\hline 25 & Spathulenol & 1575 & 1577 & $2.8 \pm 0.2$ \\
\hline 26 & Caryophyllene oxide & 1580 & 1582 & $2.9 \pm 0.2$ \\
\hline 27 & Globulol & 1590 & 1590 & $3.0 \pm 0.2$ \\
\hline 28 & Guaiol & 1600 & 1600 & $2.9 \pm 0.2$ \\
\hline 29 & t-Muurolol & 1645 & 1644 & $1.3 \pm 0.1$ \\
\hline \multirow[t]{5}{*}{30} & $\alpha$-Cadinol & 1650 & 1652 & $2.7 \pm 0.2$ \\
\hline & Monoterpene hydrocarbons & & & $28.0 \pm 0.1$ \\
\hline & Sesquiterpene hydrocarbons & & & $50.2 \pm 0.2$ \\
\hline & Oxygenated sesquiterpenes & & & $17.4 \pm 0.2$ \\
\hline & Total (\%) & & & $95.53 \pm 0.2$ \\
\hline
\end{tabular}

aLinear retention index, experimentally determined using homologous series of C6-C30 alkanes; binear retention index taken from Adams (2007) or NIST 08 (2008) and literature; 'Relative percentage values are means of three determinations \pm SD

The chemical components identified from the essential oil were thirty, forming $95.5 \%$ of the total oil composition. The essential oil consisted mainly of sesquiterpenes hydrocarbon (50.2\%), monoterpenes hydrocarbon (28.0\%), and oxygenated sesquiterpenes (17.4\%). The most abundant components of the essential oil were $\alpha$-pinene (25.4\%), germacrene D (20.2\%), $\beta$-caryophyllene (10.8\%), and $\delta$-cadinene $(6.4 \%)$. The other minor components detected in the essential oil in more than $2 \%$ were globulol (3.0\%), caryophyllene oxide (2.9\%), guaiol (2.9\%), spathulenol (2.8\%), $\alpha$-cadinol (2.7\%). $(E, E)$ - $\alpha$-farnesene (2.6\%), and germacrene B (2.4\%). In comparison to the previous study (Hisham et al., 2012), analyses of the leaf oil of Cyathocalyx zeylanicus has successfully identified thirty-two compounds, comprising $98.0 \%$ of total oil. The essential oil was reported to show high amounts of $\beta$-caryophyllene (21.6\%), $\alpha$-pinene $(20.4 \%)$ and $(E)$ $\beta$-ocimene (11.8\%). Chemical differences in the essential oil composition of plant species concerning their geographical origins and harvesting season have been reported showing that the chemical and biological diversity of aromatic and medicinal plants depend on factors such as cultivation area, climatic conditions, vegetation phase, and genetic modifications. In fact, these factors influence the plant's biosynthetic pathways and consequently, the relative proportion of the main characteristic components (Salleh et al., 2016b).

Acetylcholinesterase inhibitory activity (I\%) was tested against acetylcholinesterase (AChE) enzyme. It was compared with that of galantamine, as a standard drug against Alzheimer's disease. The essential oil indicated good AChE (I\%: $75.5 \%$ ) inhibitory activity at $1,000 \mathrm{mg} / \mathrm{mL}$ concentration, compared to galantamine which gave $85.6 \%$ inhibition. In previous reports, AChE inhibition can be explained by the high content of $\alpha$ pinene and $\beta$-pinene have anticholinesterase activity (Picollo et al., 2008). This study shows that $\alpha$-pinene as the major component in this oil hence may contribute to the AChE inhibition.

$\alpha$-Pinene is a bicyclic monoterpene widely found in nature, acting as an insect-repellent agent in plant defence (Huang et al., 2013). A variety of interesting pharmacological properties have been attributed to $\alpha$ pinene, including anti-inflammatory, bronchodilator, hypoglycemic, sedative, antioxidant, and broadspectrum antibiotic activities (Mercier et al., 2009; Violante et al., 2012; Da Silva et al., 2012). Previous studies have reported the presence of $\alpha$-pinene in the essential oils obtained from Annonaceae family, such as Polyalthia korintii (leaf oil: 43.2\%) (Sherin et al., 2018), Guatteria costaricensis (leaf oil: 36.3\%) (Palazzo et al., 2009), and Xylopia langsdorffiana (fruit oil: 34.6\%) (Moura et al., 2016). Meanwhile, germacrene D was also present as the predominant component in the oil. This component is one of the most common plant volatiles considered to be a biogenetic precursor of many sesquiterpenes such as cadinane, muurolane, and 
amorphane derivatives (Fujita, 1990). This metabolite is involved in plant-insect interaction acting as a pheromone on receptor neurons (Stranden et al., 2002). Germacrene D was also shown as an important deterrent and insecticidal agent against different parasites such as mosquitos, aphids, and ticks (Bruce et al., 2005). Previously, germacrene D was found abundant in Cardiopetalum calophyllum (flower oil: $37.03 \%$ ) (Xavier et al., 2016), Uvaria rufa (stem oil: 38.4\%) (Thang et al., 2014) and Fissistigma pallens (leaf oil: 30.2\%) (Hoferl et al., 2013), another member of the Annonaceae family.

\section{ACKNOWLEDGMENT}

The author would like to thank Department of Chemistry, Faculty of Science and Mathematics, Universiti Pendidikan Sultan Idris (UPSI) for research facilities.

\section{REFERENCES}

Adams, R. P. (2007). Identification of essential oil components by gas chromatography-mass spectrometry. 4th ed. Carol Stream (IL): Allured Publishing Corporation.

Bruce, T. J. A., Birkett, M. A., Blande, J., Hooper, A. M., Martin, J. L., Khambay, B., Prosser, I., Smart, L. E., Wadhams, L.J. (2005). Response of economically important aphids to components of Hemizygia petiolata essential oil. Pest Management Science, 61, 1115-1121.

Burkill, I. H. (1966). A dictionary of the economic product of Malay Peninsula. Kuala Lumpur: Ministry of Agriculture and Co-operatives.

Da Silva, A. C., Lopes, P. M., de Azevedo, M. M., Costa, D. C., Alviano, C. S., Alviano, D. S. (2012). Biological activities of $\alpha$-pinene and $\beta$-pinene enantiomers. Molecules, 17, 6305-6316.

Fujita, S. (1990). Miscellaneous contributions to the essential oils of plants from various territories. LI. On the components of essential oils of Torilis japonica (Houtt.) DC. Yakugaku Zasshi, 110, 771-775.

Hisham, A., Rameshkumar, K. B., Sherwani, N., Al-Saidi, S., Al-Kindy, S. (2012). The composition and antimicrobial activities of Cyperus conglomeratus, Desmos chinensis var. lawii and Cyathocalyx zeylanicus essential oils. Natural Product Communications, 7(5), 663-666.

Hoferl, M., Dai, D. N., Thang, T. D., Jirovetz, L., Schmidt, E. (2013). Leaf essential oils of six Vietnamese species of Fissistigma (Annonaceae). Natural Product Communications, 8(5), 663-665.

Huang, X., Xiao, Y., Köllner, T. G., Zhang, W., Wu, J., Wu, J., Guo, Y., Zhang, Y. (2013). Identification and characterization of $(E)$ - $\beta$-caryophyllene synthase and $\alpha / \beta$-pinene synthase potentially involved in constitutive and herbivore-induced terpene formation in cotton. Plant Physiology and Biochemistry, 73, 302-308.

IPNI (2020). International Plant Names Index. Published on the Internet http://www.ipni.org, The Royal Botanic Gardens, Kew, Harvard University Herbaria \& Libraries and Australian National Botanic Gardens.

Mercier, B., Prost, J., Prost, M. (2009). The essential oil of turpentine and its major volatile fraction (alpha- and betapinenes): A review. International Journal of Occupational Medicine Environment and Health, 22, 331-342.

Moura, A. P. G., Beltrao, D. M., Pita, J. C. L. R., Xavier, A. L., Brito, M. T., Sousa, T. K. G. D., Batista, L. M., Carvalho, J. E. D., Ruiz, A. L. T. G., Della Torre, A., Duarte, M. C., Tavares, J. F., da Silva, M. S., Sobral, M. V. (2016). Essential oil from fruit of Xylopia langsdorffiana: antitumour activity and toxicity. Pharmaceutical Biology, 54(12), 3093-3102.

Palazzo, M. C., Wright, H. L., Agius, B. R., Wright, B. S., Moriarity, D. M., Haber, W. A., Setzer, W. N. (2009). Chemical compositions and biological activities of leaf essential oils of six species of Annonaceae from Monteverde, Costa Rica. Records of Natural Products, 3, 153-160.

Picollo, M. I., Toloza, A. C., Mougabure, C. G., Zygadlo, J., Zerba, E. (2008). Anticholinesterase and pediculicidal activities of monoterpenoids. Fitoterapia, 79(4), 271-278. 
Salleh, W. M. N. H. W., Ahmad, F., Khong, H. Y. (2014). Chemical composition of Piper stylosum Miq. and Piper ribesioides Wall. essential oils and their antioxidant, antimicrobial and tyrosinase inhibition activities. Latin American and Caribbean Bulletin of Medicinal and Aromatic Plants, 13(5), 488-497.

Salleh, W. M. N. H. W., Hashim, N. A., Ahmad, F., Khong, H. Y. (2014b). Anticholinesterase and antityrosinase activities of ten Piper species from Malaysia. Advanced Pharmaceutical Bulletin, 4(2), 527-531.

Salleh, W. M. N. H. W., Ahmad, F., Khong, H. Y., Zulkifli, R. M. (2015a). Chemical compositions and biological activities of essential oils of Beilschmiedia glabra. Natural Product Communications, 10(7), 1297-1300.

Salleh, W. M. N. H. W., Ahmad, F., Khong, H. Y. (2015b). Antioxidant and anticholinesterase activities of essential oils of Cinnamomum griffithii and C. macrocarpum. Natural Product Communications, 10(8), 1465-1468.

Salleh, W. M. N. H. W., Ahmad, F., Khong, H. Y., Zulkifli, R. M. (2016a). Essential oil composition of Malaysian Lauraceae: A mini review. Pharmaceutical Sciences, 22, 60-67.

Salleh, W. M. N. H. W., Ahmad, F., Khong, H. Y., Zulkifli, R. M. (2016b). Comparative study of the essential oils of three Beilschmiedia species and their biological activities. International Journal of Food Science \& Technology, 51, $240-249$.

Sherin, A. R., Asla Kukku, K., Leela, N. K. (2018). Monoterpenes rich essential oils from the leaves of Polyalthia korintii (Dunal) Benth. and Hook.F. (Annonaceae) from Kerala. Asian Journal of Pharmaceutical and Health Sciences, 8(4), 20192023.

Stranden, M., Borg-Karlson, A. K., Mustaparta, H. (2002). Receptor neuron discrimination of the germacrene D enantiomers in the moth Helicoverpa armigera. Chemical Senses, 27, 143-152.

Thang, T. D., Luu, H. V., Tuan, N. N., Hung, N. H., Dai, D. N., Ogunwande, I. A. (2014). Constituents of essential oils from the leaves and stem barks of Uvaria rufa and Uvaria cordata (Annonaceae) from Vietnam. Journal of Essential Oil Bearing Plants, 17(3), 427-434.

Violante, I. M., Garcez, W. S., Barbosa Cda, S., Garcez, F. R. (2012). Chemical composition and biological activities of essential oil from Hyptis crenata growing in the Brazilian cerrado. Natural Product Communications, 7, $1387-1389$.

Wang, R. J., Saunders, R. M. K. (2006). A synopsis of Cyathocalyx species (Annonaceae) in Peninsular Malaysia, Sumatra, and Borneo, with descriptions of two new species. Botanical Journal of the Linnean Society, 152, 513-532.

Wijeratne, E. M. K., De Silva, L. B., Kikuchi, T., Tezuka, Y., Gunatilaka, A. A. L., Kingston, D. G. I. (1995a). Cyathocaline, an azafluorenone alkaloid from Cyathocalyx zeylanica. Journal of Natural Products, 58(3), 459-462.

Wijeratne, E. M. K., De Silva, L. B., Tezuka, Y., Kikuchi, T. (1995b). Clerodane diterpenoids from Cyathocalyx zeylanica. Phytochemistry, 39(2), 443-445.

Xavier, M. N., Alves, C. C. F., Cazal, C. M., Santos, N. H. (2016). Chemical composition of the volatile oil of Cardiopetalum calophyllum collected in the cerrado area. Ciencia Rural, 46(5), 937-942. 